\section{Rhodamin-B increases Hippocampus cell apoptosis in Rattus norvegicus-oxidative stress related to Parkinson, Alzheimer, cancer, hyperactive, anterograde amnesia diseases}

\author{
Dewi Ratna Sulistina, ${ }^{1}$ I Wayan Arsana \\ Wiyasa, ${ }^{2}$ Windhu Purnomo ${ }^{3}$ \\ ${ }^{1}$ Doctoral Program of Public Health, \\ Faculty of Public Health, Universitas \\ Airlangga; ${ }^{2}$ Division of Fertility, \\ Endocrinology and Reproduction, \\ Obstetric and Ginecology Laboratory, \\ Saiful Anwar General Hospital; Faculty \\ of Medicine, Brawijaya University, \\ Malang, East Java; ${ }^{3}$ Biostatistics and \\ Population Department, Faculty of \\ Public Health, Universitas Airlangga, \\ Indonesia
}

\begin{abstract}
Rhodamine $\mathrm{B}$ is a textile dye compounds containing chlorine $\left(\mathrm{Cl}^{-}\right)$, alkylating ( $\mathrm{CH} 3-\mathrm{CH} 3)$, Poly Aromatic Hydrocarbons $(\mathrm{PAH})$ which activate the enzyme cytochrome P-450 as well as the structure of quinone which is very redox that leads to the formation of Reactive Oxygen Species (ROS). ROS increases induce apoptosis of the intrinsic pathway. The imbalance ratio between BAX and BCL-2 stimulates apoptosis in Hippocampus tissue. "The selected design was "the post test only control group" using twenty-eight Wistar female Rattus norvegicus mouse age of 10-12 weeks. There was a significant difference ( $\mathrm{p}$-value $<0.05$ ) of total BCL-2 expression between the control group to the treatment group. Correlation coefficient of 0.945 indicates that the level of the relationship/ correlation is very strong category. Increasing doses of Rhodamine $\mathrm{B}$ was given, accompanied by the decrease in the expression of BCL-2. Correlation coefficient of -0.731 indicates that the level of the relationship/ correlation belongs strong category. It is concluded that Rhodamin B has been verified as capable to increase the expression of BAX and to reduce the expression of $\mathrm{BCL}-2$ in hippocampus tissue on Rattus norvegicus.
\end{abstract}

\section{Introduction}

Although the ban on the use of Rhodamine B dyes has been regulated in the Minister of Health Regulation No. 722/
Menkes/Per/VI/88 and Permenkes RI No. 239/Menkes/Per/V/85 but the wider community still uses Rhodamin B in food processing. . $^{1,2}$

Rhodamin B is known to have toxic, carcinogenic and genotoxic effects. ${ }^{3}$ The effect of Rhodamin B if it is consumed for a long time is that it will continuously cause irritation in the respiratory, eye disorders, bladder cancer, liver damage, heart, lymph, kidney, pancreas, central nervous system and brain damage., ${ }^{4,5}$ Rhodamine $\mathrm{B}$ oral exposure in male and female rats for 30 days caused structural damage to liver histology, renal macroscopic changes, histopathology of the kidney proximal tubules of male mice, low radioactivity uptake in the brain, inhibited growth, diarrhea, death, lymphatic liver cancer, bladder dilation, liver poisoning, loss of body weight, body cell volume, total serum protein, discoloration, degradation of hair and skin become red and rough, abnormal behavioral changes (aggressive, cannibal), intrauterine death, impaired growth and internal abnormalities of the fetus, cell damage to liver and kidneys in pregnant rats Rattus norvegicus. ${ }^{6-13}$

Rhodamin B has a quinon structure which is a very redox active molecule causing the formation of ROS (reactive oxygen species) which leads to oxidative stress and cell injury to target cells (CNS, hypothalamus, Adenohypophisis). Increased ROS in the blood induces the cell apoptosis phase. Induction of apoptosis in hippocampal tissue is involved in various diseases, especially Alzheimer's. ${ }^{14,15}$

Hippocampus is a small organ located in the medial temporal lobe of the brain and is an important part of the limbic system which is the area that regulates emotions, memory, especially long-term memory and plays an important role in spatial navigation. Damage to the hippocampus can cause memory loss and difficulties in building new memories. In Alzheimer's disease, hippocampus is one of the first areas of the brain that is affected causing confusion and memory loss so that it is often seen in the early stages of this disease. ${ }^{15}$

In this study, researchers focused on the effects of Rhodamine B on the expression of BAX (Bcl-2 Antagonist X) and BCL-2 (B-cell lymphoma-2) in the hippocampal tissue in Rattus norvegicus.

\section{Materials and Methods}

Rattus norvegicus Wistar strain female mouse, healthy, aged 10-12 weeks found in the experimental animal raising unit
Correspondence: Dewi Ratna Sulistina, Doctoral Program of Public Health, Faculty of Public Health, Universitas Airlangga, Jl. Mulyorejo, Surabaya, Jawa Timur 60115, Indonesia.

Tel.: +62315920948 - Fax: +62315924618.

E-mail: dewi.ratna.sulistina-2018@fkm.unairac.id.

Key words: rhodamine B, BAX, BCL-2, hippocampus tissue.

Contributions: the authors contributed equally.

Conflict of interests: the authors declare no potential conflict of interest.

Funding: none.

Clinical trials: This research has been approved by research ethics committee of Faculty of Medicine Brawijaya University, Malang, Indonesia.

Conference presentation: part of this paper was presented at the $3^{\text {rd }}$ International Symposium of Public Health, 2018 October 31-November 1, Universitas Airlangga, Surabaya, Indonesia.

Acknowledgment: the authors would like to thank all technicians in Laboratory of Pharmacology, Pathology and Biomedical Science for helping this study.

Dedication: the article is dedicated to Doctoral Program of Public Health, Faculty of Public Health, Universitas Airlangga, Surabaya, Indonesia

Received for publication: 28 July 2019.

Revision received: 9 September 2019.

Accepted for publication: 15 October 2019.

This work is licensed under a Creative Commons Attribution NonCommercial 4.0 License (CC BY-NC 4.0).

(C) Copyright: the Author(s), 2019

Licensee PAGEPress, Italy

Journal of Public Health in Africa 2019; 10(s1):1175 doi:10.4081/jphia.2019.1175

(UPHP) with the consideration that mice are experimental mammals (laboratory animals) as a research model before being treated in humans.

The experimental animals were all adapted first at room temperature of $22-25^{\circ}$ C for 11 days at the UB Pharmacology Laboratory, Faculty of Medicine. Before being given treatment, rats were synchronized with the estrous cycle with the whitten method for 5 days. Then, the rats were grouped into the control group (given standard feed ad libitum), group I 
(given standard feed and Rhodamin B dose $150 \mathrm{ppm}$ (4.5 mg/ $200 \mathrm{gBW})$, group II (given standard food and Rhodamin B dose $300 \mathrm{ppm}$ (9 mg/ $200 \mathrm{gBW}$ ), group III (given standard food and Rhodamin B 600 ppm dose (18 mg/ $200 \mathrm{gBW})$. Rhodamine B was given per sonde for 36 days.

After 36 days of exposure to Rhodamin $\mathrm{B}$, all rats were anesthetized using inhaled chloroform, the mice were turned off and hippocampus tissue samples were taken by surgery on the brains of rats and put into $10 \%$ formalin solution and carried out the hippocampus tissue removal slice by observing the mouse brain anatomy for making slides.

Analysis of BAX and BCL-2 expression in hippocampus tissue using immunohistochemical staining was conducted and observed with a microscope. Brown hippocampus tissue shows BAX and BCL-2 expression, while if it is purple, it shows no expression of BAX and BCL-2. The calculation of BAX and BCL-2 expressions based on weak color intensity (1), medium (2), strong (3), very strong (4) using the help of OliVIA software. Data results are then processed using SPSS for Windows software.

This study has passed ethics at the Ethics Committee of the Medical Faculty of the University of Brawijaya.

Table 1. Comparison of the effects of Rhodamine B on BAX expression with the Kruskal-Wallis test.

\begin{tabular}{lcc} 
Treatment & Mean \pm SD & p-value \\
Control & $2.57 \pm 1.27^{\mathrm{a}}$ & 0.000 \\
$4,5 \mathrm{mg}$ & $6.43 \pm 2.5^{\mathrm{lbc}}$ & \\
\hline $9 \mathrm{mg}$ & $11.57 \pm 3.21^{\mathrm{cd}}$ & \\
$18 \mathrm{mg}$ & $18.71 \pm 1.11^{\mathrm{d}}$ & \\
\hline
\end{tabular}

On average $\pm S D$, if it contains different letters, it means that there are significant differences, while if you load the same letter, it means that there is no meaningful difference.

Table 2. Comparison of the effects of Rhodamine B on BCL-2 expression with Anova.

\begin{tabular}{lcc} 
Treatment Mean \pm SD & p-value \\
Control & $7 \pm 1.155^{\mathrm{c}}$ & 0.000 \\
$4,5 \mathrm{mg}$ & $4.571 \pm 2.07^{\mathrm{b}}$ & \\
\hline $9 \mathrm{mg}$ & $2.714 \pm 1.38^{\mathrm{a}}$ & \\
$18 \mathrm{mg}$ & $2.286 \pm 0.756^{\mathrm{a}}$ & \\
\hline
\end{tabular}

Table 3. Rhodamin B correlation test for BAX and BCL-2 expression.

\begin{tabular}{lccc} 
Variable & Correlation coefficient & p-value & Description \\
Expression of BAX & 0.945 & 0.000 & Significant \\
Expression of BCL-2 & -0731 & 0.000 & Significant \\
\hline
\end{tabular}

other words, giving Rhodamin $\mathrm{B}$ with a dose of $9 \mathrm{mg} / 200 \mathrm{gBW}$ and $18 \mathrm{mg} / 200$ gBW gave the same effect on the decrease in BCL-2. Based on the results of the analysis, it can be seen that the dose of Rhodamine B which can significantly reduce $\mathrm{BCL}-2$ to the lowest point is the dose of $18 \mathrm{mg} / 200 \mathrm{gBW}$ but not significantly different from the dose of $9 \mathrm{mg} / 200 \mathrm{gBW}$. Rhodamin B dosage at all levels can significantly reduce BCL-2.

Based on the results of testing the correlation between Rhodamin B administration and BAX expression, a correlation coefficient of 0.945 with a $\mathrm{p}$ value of 0.000 was obtained. At the $5 \%$ error level $(\alpha=0.05)$, it was shown that the p-value obtained was less than 0.05 $(p<0.05)$. From this test, it can be seen that there is a significant relationship between Rhodamin B administration and BAX expression. On the results of testing the correlation between the administration of Rhodamin B with BCL-2 expression, a correlation coefficient was found at -0.731 with a p-value of 0.000 . At the $5 \%$ error level $(\alpha=0.05)$, it was shown that the $p$ value obtained was less than $0.05(\mathrm{p}<0.05)$. From this test it can be seen that there is a significant relationship between Rhodamine administration and BCL-2 expression.

Meanwhile, the highest average expression of BAX was shown by the group of rats exposed to Rhodamin B at a dose of $18 \mathrm{mg} /$ $200 \mathrm{gBW}$, which was 18.71 but not significantly different from the administration of $9 \mathrm{mg} / 200 \mathrm{gBW}$. This shows that the highest increase in BAX expression is shown in doses of $9 \mathrm{mg}$ and 18 mg.

Based on the results of the analysis using ANOVA, it was obtained a p-value of 0,000 , smaller than $\alpha=0.05(p<0.05)$. So, from this test, it can be concluded that there is a significant effect of Rhodamin B on the decrease in BCL-2. In other words, there is a significant difference in BCL-2 due to different doses of Rhodamine B. In the comparison of all levels of the treatment group, a p-value of less than 0.05 was obtained except in the comparison between the dose of $9 \mathrm{mg} / 200 \mathrm{gBW}$ with $18 \mathrm{mg} / 200$ $\mathrm{gBW}$. This shows that there is no difference in average BCL-2 between groups of rats given Rhodamin B at a dose of $9 \mathrm{mg} / 200$ $\mathrm{gBW}$ at a dose of $18 \mathrm{mg} / 200 \mathrm{gBW}$. Or in

\section{Conclusions}

Rhodamin $\mathrm{B}$ has been verified as capable to increase the expression of BAX, to reduce the expression of $\mathrm{BCL}-2$ in hippocampus tissue on Rattus norvegicus.

\section{References}

1. O'Neil MJ. The Merck Index, Merck Sharp \& Dohme Corp., a subsidiary of Merck \& Co., Inc; 2006.

2. RI POM Agency. 138/5000 Poison Information Center, Drug and Food Information Center, Guidance for Poisoning for Puskesmas, Book IV Food Additives; 2005.

3. Zakaria A. Inhibition Of Carmoisine And Rhodamine Toxic Effects On At's Spleen Lymphocytes Proliferation Activity By Urtica Dioica L. Leaf Extract. Bogor: Department of Food Science and Technology, Faculty of Agricultural Tecnology, Bogor Agricultural University, I; 2011.

4. Camihort G, Gómez Dumm C, Luna G, et al. Relationship between pituitary and adipose tissue after hypothalamic denervation in the female rat. A morphometric immunohistochemical 
study. Cells Tissues Organs 2005;179(4):192-201.

5. Srideni D. Dangers of Chemicals for Health; 2011.

6. Sihombing G. An exploratory Study on Three Synthetic Colouring Matters Commonly Used Food Colours in Jakarta. Tesis S2 yang dipublikasikan. Badan Litbang Kesehatan, Departemen Kesehatan dan Kesejahteraan Sosial 1978. Available from: http//digilib.litbang.go.id. Accessed on: 3 March 2018.

7. Muchtadi D, Nienaber NL. Forbidden Toxicity for use in food and beverages. Paper presented at the Meeting of the Use of Food Additives (BTM) by the Food Industry February 25. Jakarta: Collaboration with the Ministry of State for Food Affairs with the Department of Engineering; 1997.

8. Siswati P, Slamet J. Toxicity test for rhodamine food dyes on liver tissue of Australian mice (Mus musculus). J Toksikol Ind 2000;1(3):18-27.

9. Anggraeny F. Effect of Rhodamine B on liver of mice (Mus musculus) embryos of balb-C strains. Malang: State University of Malang; 2010.

10. Manurung R. Benefits of Honey for Changes in Ureum and Creatinine Levels and Macroscopic Kidney and Histopathology of Kidney Proximal Tubules Male Male Mus musculus Given Rhodamin B. Medan: Biomedical Science Study Program at the Faculty of Medicine University; 2011.

11. Bao X, Lu S, Morse C. Rhodamine-123 Synthesis and Biodistribution in Rodents. Molecular Imaging Branch, National Institute of Mental Health. Pubmed Nucl Med Biol. 2012;39(8):1128-36.
12. Handrianto Z. The Effect of Granting The Dye Rhodamin B in The Organogenesis of Rats (Rattus norvegicus). Jurusan Biologi FKIP Universitas Sebelas Maret Surakarta; 2012.

13. Fatimah U. Histological Structure in Hepar and Ren of Pregnant Female Rats (Rattus norvegicus) After Orally Feed of Rhodamine B. Available from: http://digilib.mipa.uns.ac.id/detailpenel itian-M04-1191. Accessed on: 3 March 2018.

14. Fiers W. More Than One Way To Die: Apoptosis, Necrosis And Reactive Oxygen Damage. Oncogene 1999;18: 7719-7730.

15. Nicholls DG, Budd S. Mitochondria And Neuronal Survival. Physiol. Rev. 2000;80:315-360. 